\title{
Factors affecting postpartum ovarian activity of goats in tropical semi-arid region
}

\section{Factores que afectan la actividad ovárica posparto de las cabras en la región semiárida tropical}

Thiago Vinicius Costa Nascimento ${ }^{1}$, Edilson Soares Lopes Júnior ${ }^{2}$, Mayara de Souza Miranda ${ }^{3}$, Thais Thatiane dos Santos Souza ${ }^{2}$, Ana Arlete de Amorim Silva ${ }^{2}$, Anny Graycy Vasconcelos de Oliveira Lima ${ }^{1}$, Daniel Maia Nogueira ${ }^{4}$, Mabel Freitas Cordeiro ${ }^{2}$, Salete Alves de Moraes ${ }^{4}$, Tadeu Vinhas Voltolini ${ }^{4}$

Originales: Recepción: 27/03/2020 - Aceptación: 05/10/2020

\section{INDEX}

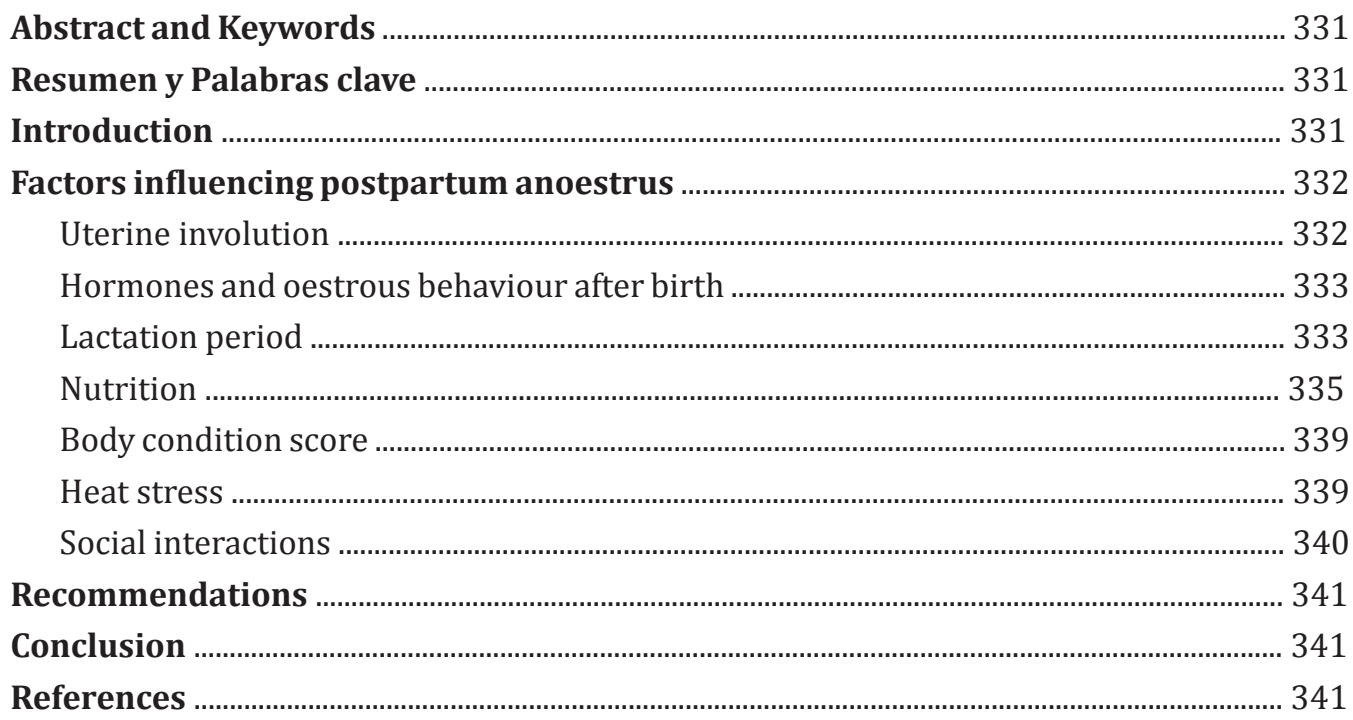

1 Posgraduates program Animal Sciences of Universidade Federal do Maranhão. Rod. BR. 222. Km 04. S/N.65500-000. Chapadinha. Maranhão. Brasil. thiagovcn_vet@ hotmail.com

2 LAFIBRA - Laboratory of Physiology and Biotechnology of Animal Reproduction at Universidade Federal do Vale do São Francisco. Rod. BR. 407. Km 12. Lot. 543. S/N. 56300-990. Petrolina. Pernambuco. Brasil.

3 Posgraduates program Animal Sciences of Universidade Federal da Bahia. Av. Adhemar de Barros. 500. Ondina. 40170-110. Salvador. Bahia Salvador. Bahia. Brasil.

4 CPATSA - EMBRAPA - Agricultural Research Center of the Semi-Arid Tropic. Brazilian Agricultural Research Corporation (Embrapa). Rod BR-428. Km 152. S/N. 56302970. Petrolina. Pernambuco. Brasil. 


\begin{abstract}
There have been few studies on the use of diets and strategies to reduce the postpartum anoestrus in dairy goats, especially in tropical semi-arid regions. This review discusses the factors influencing the return of postpartum ovarian activity in goats. The duration of puerperal anoestrus in goats directly affects the productivity of the herd. During the postpartum period, goats showed a puerperal anoestrus due to physiological changes in their reproductive tract to achieve a new conception. Anoestrus occurs as a result of tissue renewal in the uterus (uterine involution) which is associated with the return of cyclic ovarian activity, and is influenced by factors such as suckling of the offspring, the period of lactation, social interactions, body condition score (BCS) before and after birth, intensity of negative energy balance (NEB) and stress from adverse climatic conditions for example; the heat. The period of anoestrus can be extended, due to the delay in the cyclic reproductive activity in the puerperium. To minimize the negative effects of postpartum anoestrus on productivity, we recommend a mating season and a plan for the kidding period, as well as a program to increase the BCS during pregnancy so that the animals will have a better BCS at parturition and a nutritional plan for the lactation period.
\end{abstract}

\title{
Keywords
}

Anoestrus • Negative Energy Balance $\bullet$ Puerperium

\section{RESUMEN}

Se han realizado pocos estudios sobre el uso de dietas y estrategias para reducir la duración del anoestro postparto en cabras lecheras, especialmente en regiones semiáridas tropicales. Esta revisión analiza los factores que influyen en el retorno de la actividad ovárica posparto. La duración del anestro puerperal en las cabras afecta directamente la productividad del hato. Durante el período posparto, las cabras presentan un anestro puerperal debido a cambios fisiológicos en su tracto reproductivo para lograr una nueva concepción. El anestro se presenta como consecuencia de la renovación tisular del útero (involución uterina) que está asociada con el retorno de la actividad ovárica cíclica, y está influenciada por factores como la succión de las crías, el período de la lactancia, las interacciones sociales, la condición corporal (CC) antes y después del parto, la intensidad de un balance energético negativo (NEB) y el estrés por las condiciones climáticas adversas como por ejemplo; el calor. El período del anestro se puede extender, debido al retraso en la reanudación de la actividad reproductiva cíclica por el puerperio. Para minimizar los efectos negativos del posparto en la productividad, recomendamos una temporada de apareamiento y una planificación para el período de parición, así como un programa para incrementar la CC durante la gestación para que los animales tengan una mejor CC en el parto y un plan nutricional para el período de lactancia.

Palabras clave

Anestro • Balance Energético Negativo • Puerperio

\section{INTRODUCTION}

Most goat herds in Brazil (90\%) are raised in the north-eastern region, mainly using an extensive management system. This management system shows low productivity indices, low fertility, high mortality from birth to weaning and long kidding intervals. All these factors result in low reproductive efficiency, with herds producing only a small number of kids per year (64).

Low nutrient availability is one of the main causes of deficient productivity indices, as it is strongly related to reproductive parameters and could stop reproductive activity in females. The lack of feed is mainly a problem during the dry season, when substantial reductions in the quality and amount of feed availability reduce the body condition of animals and productive or reproductive capacity in small ruminants (69). 
Several studies have shown that the nutritional and metabolic states of animals may affect reproductive functions. While little is known about the mechanisms linking nutrition and the activity of the hypothalamus-pituitary-ovarian axis during postpartum anoestrus, it is known that energy is the main nutrient required by females during reproduction, and that its insufficient supply reduces reproductive efficiency $(30,39)$.

The main factors influencing postpartum anoestrus are: 1) uterine involution, 2) lack of positive feedback from the hypothalamus-pituitary-ovarian axis causing reduction of ovarian activity after parturition and return to oestrus, 3) lactation period, 4) pre- and postpartum state of nutrition of the mother, 5) body condition and 6) environmental causes, such as heat stress and social interactions $(39,59)$. This review aims to clarify how these factors are related to reproductive physiology, endocrinology and follicular dynamics and in turn, how they influence the return of postpartum ovarian activity in goats.

\section{FACTORS INFLUENCING POSTPARTUM ANOESTRUS}

\section{Uterine involution}

Goats are seasonal polyestrics, but when reared in tropical regions they may exhibit reproductive activity throughout the year (17). However, during the postpartum period, the ovaries are unable to promote follicles to preovulatory status because of inhibition of the hypothalamic-pituitary axis resulting in a period of anoestrus (puerperal or postpartum) until the goats exhibit oestrous behaviour (46). During this postpartum period, ovarian activity is restored after uterine involution occurs. This process is considered essential to produce a new conception. During this postpartum period, ovarian activity is re-established after the uterine involution occurs. Involution of the uterus is fundamental to producing a new conception and it requires several physiological processes, such as a reduction in the size of the uterus, loss of tissues, repair of the residual tissues and reduction of tissue fluid (55).

Uterine involution is necessary for the return to reproductive activity after parturition. The uterus returns to its pre-pregnancy cellular and spatial conditions via uterine contraction that expels residual material from the placenta, lochia (genital secretion composed of mucus, blood, residual foetal membranes and fluids) (26), preventing possible bacterial infections that can delay the involution and microscopic regeneration of the endometrium (24). Endometrial regeneration is linked to the type of placenta present in each species. For instance, the cotyledonary placenta in ruminants lengthens the time required for regeneration compared with the diffuse placenta in mares (4). According to Olivera et al. (2013) the uterus of goats requires 4 to 5 weeks for involution. This period may be extended depending on the degree of contamination, the retention of foetal membranes (26) and oestrogen production. Mirzaei et al. (2011) and Takayama et al. (2010) reported that uterine involution varies according to breed (size, rusticity, performance), order of parity, type of birth, lactation and nutrition-associated factors and season of birth. These factors are reviewed and discussed below.

Ababneh and Degefa (2005) verified, through ultrasound evaluation and slaughter, that uterine involution was completed in Balady goats and that they were ready for a new pregnancy at 19 days after birth. This can be attributed to the small size of Balady goats, which have a bodyweight of less than $20 \mathrm{~kg}$. Similar results were observed by Degefa et al. (2006) for the same breed of goats and by Takayama et al. (2010) in Shiba goats, which have a similar size and bodyweight. Salmito-Vanderley and Marques Júnior (2004) reported that uterine involution in animals of undefined genotype is completed by the $30^{\text {th }}$ day after the kid's birth. Greyling and Van Niekerk (1991) studied Boer goats, slaughtering them at different intervals between parturition and 34 days postpartum to observe all macroscopic uterine sizes, and reported that involution ended approximately 28 days after birth. Krajničáková et al. (1999) reported this process ending on the $34^{\text {th }}$ day after parturition. These studies show that body size is important in determining the time the animal needs for the uterus to return to its initial size.

The number of parturitions (order of parity) and the number of kids (type of birth) can modify the size of the uterus pre- and postpartum, respectively, and also affect the time to uterus involution. According to Webb et al. (2007), primiparous females show longer postpartum anoestrus, because the mother is nursing for the first time and is still growing. 
In addition, depending on body condition at first mating, young females may still be completing their body development, which increases the demand for energy and protein. Combined with gestational demands, this promotes additional stress, leading to longer postpartum anoestrus $(21,59)$.

Eloy et al. (2003) stated that after uterine involution, a female might be ready to begin a new pregnancy, but lactation and nutrition-associated factors contribute to extending the postpartum anoestrus, highlighting the importance of these two factors on uterine involution.

Nogueira et al. (2011) reported that season of birth (rainy or dry season) interferes with the duration of postpartum anoestrus more than the period of lactation, via modification of feed availability in the environment. Mendoza et al. (2020) reported that the use of volatile compounds of the herbal methionine and choline can improve performance and immuno-metabolic status especially in the first days of postpartum.

In summary, studies on uterine involution time remain scarce. They show that this process is affected by many different factors, but generally occurs between 20 and 45 days after parturition (61).

\section{Hormones and oestrous behaviour after birth}

The oestrous cycle is interrupted during the puerperium, due to the inhibition of the several levels of the complex interactions between the hypothalamus, pituitary and ovaries that regulate the reproductive cycle. The absence of oestrous behaviour during puerperium is caused by low follicular development, which reduces the production of estradiol and consequently inhibits the hypothalamic-pituitary-gonadal feedback, hence interrupting the oestrous cycle.

In the post-partum anoestrus, GnRH (gonadotropin releasing hormone) release is inhibited and constitutes a limiting factor for the recovery of ovarian activity (33). Consequently, both LH (luteinizing hormone) release and FSH (follicle stimulating hormone) pulses are reduced (29). Schirar et al. (1989a) found that the first LH surge in ewes was affected according to whether the offspring was suckling, being faster (up to 10 days) if non-suckling or longer (up to17 days) if suckling.

In sheep, FSH secretion increases progressively after delivery and reaches its peak around 20 days after birth, promoting follicular development (72).

The first ovarian cycle after an anoestrus period in goats is not preceded by the usual oestrous activity and both the duration and concentration of progesterone secretion by the corpus luteum are generally lower than normal (17). In ewes, the first two ovulations are of poor quality, due to the low pulsatility of FSH, due to the fact that the small follicles have a low number of granulosa cells, which produce low levels of estradiol, which may explain the possible absence of sexual receptivity prior to the first ovulation (33), known as "silent ovulation" (59).

During lactation, the influence of prolactin and endogenous opioids, such as $\beta$-endorphins, which inhibit the secretion of GnRH as well as FSH- and LH-releasing hormones (FSH-RH and LH-RH), reduces the frequency of LH pulses $(13,25,44,76)$. This reduction in the pulses of LH induces small corpora lutea, which in turn reduce the release of progesterone to levels that may not be enough to maintain gestation (17). The LH release is influenced by body condition, which will be discussed in more detail later.

Shi et al. (2015) found that oestrogen receptors (ER $\alpha$ and $E R \beta$ ) and progesterone receptors (PR) are responsible for modulating follicular responses, and that the expression of ER $\beta$ is intrinsically related to the number of granulosa cells in the follicle; for these reasons, ovarian activity is not always associated with oestrous behaviour.

Schirar et al. (1989b) found that a faster uterine involution may be associated with increased production of prostaglandin (PGF2 $\alpha$ ). According to these authors, PGF2 $\alpha$ promotes the uterine defence mechanism, with effects on leukocytes, and stimulation of smooth muscle, causing myometrial contractions that help expel the uterine lochia, or other content, in addition to promoting the release of gonadotropins that affect oestrogen production.

\section{Lactation period}

Lactation has an important effect on the duration of postpartum anoestrus in ruminants. The duration of lactation and milk production have negative effects on the recovery of reproductive activity after parturition in goats raised in tropical regions (67). 
At the start of the postpartum period, lactation is accompanied by high levels of prolactin and endogenous opioids are released in the milk ejection process (25). Prolactins act directly in inhibiting the secretion of other hormones from the anterior pituitary, mainly the LH (13). If LH is absent, ovarian follicles will not develop or will secrete low concentrations of steroids under the influence of FSH (21). The inhibition associated with nursing may be caused by the temporary alteration of this feedback, involving the temporary reduction of GnRH (67).

In addition, endogenous opioids, such as $\beta$-endorphin, $\mu, \kappa$ and $\delta$-opioids produced during the lactation period, inhibit the hypothalamic production of GnRH, mainly LH, as a result of the inhibition of the releasing hormones of LH (LHRH) and FSH (FSHRH) (13, 52). Stressed animals (due to other factors, i.e. thermal stress) can suffer an increase in the plasma concentrations of endogenous opioids from postpartum and therefore suffer a decrease in reproductive efficiency (42).

Lactation commonly has a suppressive effect on ovarian activity. The lactation period is associated with the production of both oxytocin and prolactin. Oliveira et al. (2013) and Gaafar et al. (2005) described an inverse correlation between prolactin concentration and oestrus activity in ewes in seasonal anoestrus. During milk production, prolactin concentration is increased due to the stimulus provided by suction from kids. As the lactation period proceeds, prolactin secretion decreases, allowing the recovery of normal ovarian activity (21). Lactation and milk production increase nutritional demands, therefore causing a negative energy balance (NEB) that affects the duration of postpartum anoestrus (53). Lactation also increases the release of oxytocin that promotes milk-ejection from the myoepithelial cell's contraction (16). In addition, the oxytocin causes contraction of the uterus by myometrial contractions stimulating the endogenous release of PGF $2 \alpha$ that in the first postpartum days acts by accelerating the expulsion of lochia and causing an earlier uterine involution (16).

Faraz et al. (2020) reported some studies that found no deleterious effects of oxytocin on the reproductive health in females due to the oxytocin had a short life span of about 2.5 minutes, however, in this same review it is mentioned that goats increase the concentration of oxytocin at the beginning of milking and concomitantly with the increase in prolactin; it is assumed that in order for lactogenesis to be maintained, milk must be removed from the mammary gland. The sensorial stimulus of teat suction by kids stimulates the production of prolactin, which inhibits the release of dopamine and GnRH-associated peptides. As these are essential for the synthesis of gonadotropins, their inhibition results in a reduction in ovarian activity (36). There is a relationship between the duration of postpartum anoestrus and the degree of teat stimulation. Because of this, management of weaning of the kids affects directly the postpartum anoestrus. Falcão et al. (2008) observed that SRD goats in continuous lactation have a longer period of postpartum anoestrus than goats under controlled lactation management in which the kids were isolated from their mothers during the day and suckling occurred only twice a day (table 1, page 335). Similarly, in goats treated with $\mathrm{PGF}_{2 \alpha}(36)$, the duration of the postpartum anoestrus was shortened in controlled lactation compared to continuous lactation, while $\mathrm{PGF}_{2 \alpha}$ treatment shorten the anoestrous period even more. However, Maia and Costa (1998) observed that Canindé goats subjected to a controlled lactation management plan showed a longer postpartum anoestrus. This longer postpartum anoestrus could be attributed to the handling stress experienced by the Canindé goats, which might have influenced the anoestrous length. In native breed goats, such as those reported by Maia and Costa (1998), controlled suckling of the offspring can cause elevation of cortisol levels, which may have a deleterious effect on the release of GnRH and consequently increase the anoestrus period. However, in animal breeds that are accustomed to daily handling, such as dairy goats, controlled suckling can reduce the anoestrous period, due to a less teat stimulation. In the other hand, PGF2 $\alpha$ treatment can shorten the anoestrous period even more because prostaglandin promotes uterine involution by stimulating the immune system and influencing inflammatory processes in the uterus, thus reducing the time required for uterine involution. In addition, it can stimulate the release of FSH and LH, and consequently, reduce the duration of postpartum anoestrus (63). As shown in table 1 (page 335), the weaning management of kids directly affects postpartum anoestrus. 
Table 1. Influence of the suckling of offspring on the duration of postpartum anoestrus (days) in different breeds of goats.

Tabla 1. Influencia del amamantamiento de la descendencia en la duración del anestro posparto (días) en diferentes razas de cabras.

\begin{tabular}{|c|c|c|c|}
\hline Animals & Continuous $^{1}$ & Controlled $^{2}$ & Authors \\
\hline SRD Goats & $95.00 \pm 4.70 \mathrm{a}$ & $75.10 \pm 3.70 b$ & \multirow{3}{*}{$\begin{array}{l}\text { Falcão, D. P. } \\
\text { et al. (2008) }\end{array}$} \\
\hline${ }^{3} \mathrm{SRD}$ Goats treated with $\mathrm{PGF}_{2 \alpha}$ & $68.80 \pm 8.40 \mathrm{a}$ & $47.90 \pm 3.10 \mathrm{~b}$ & \\
\hline${ }^{4}$ SRD Goats treated with PGF2 $\alpha$ & $69.70 \pm 0.70 \mathrm{a}$ & $49.20 \pm 3.00 \mathrm{~b}$ & \\
\hline Canindé Goats & $33.09 \pm 3.48 \mathrm{a}$ & $46.44 \pm 3.44 b$ & $\begin{array}{c}\text { Maia and } \\
\text { Costa (1998) }\end{array}$ \\
\hline
\end{tabular}

1: The goat kids remained with the mothers; ${ }^{2}$ : The kids were isolated from their mothers during the day and suckling occurred only twice a day. ${ }^{3}: 250 \mu \mathrm{g}$ of PGF $2 \alpha$ in $6^{\text {th }}$ and $12^{\text {th }}$ day postpartum; ${ }^{4}: 250 \mu \mathrm{g}$ of PGF $2 \alpha$ in $6^{\text {th }}, 7^{\text {th }}$, $8^{\text {th }}, 9^{\text {th }}$ and $10^{\text {th }}$ day postpartum. Values with different letters in the same row are significantly different at $P<0.05$.

${ }^{1}$ : Los cabritos permanecieron con las madres; ${ }^{2}$ : Los cabritos fueron aislados de sus madres durante el día y la succión de la descendencia ocurrió solo dos veces al día. ${ }^{3}: 250 \mu \mathrm{g}$ de PGF2 $\alpha$ en el sexto y duodécimo día de posparto; ${ }^{4}: 250$ ug de PGF2 $\alpha$ en el sexto, séptimo, octavo, noveno y décimo día de posparto. Los valores con letras diferentes en la misma fila son significativamente diferentes en $\mathrm{P}<0,05$.

Other factors influencing the anoestrus postpartum period are type of breed, age and parity order and type of birth (single or multiple) (19). The same authors observed that the interval to the first oestrus after parturition was $78.93 \pm 7.61$ days in Anglo-Nubian goats, compared with $95.26 \pm 11.8$ days in Saneen goats, which are better milk producers. In the same study, primiparous animals showed longer postpartum anoestrus than multiparous females $(\mathrm{p}<0.05)$, in both Anglo-Nubian $(89.10 \pm 9.73$ vs. $56.33 \pm 7.78)$ and Saanen goats $(133.50 \pm 12.71$ vs. $52.78 \pm 5.51)$. These differences may be attributed to the fact that primiparous females are usually still maturing; in the final third of gestation the foetus occupies a lot of space in the abdominal cavity and the female cannot consume high amounts of feed, even though females with a low body condition score or small size still need to complete their own body development. He et al. (2015) suggested the use of feed concentrates starting from 100 days of pregnancy to minimize the drop-in body condition score and thus facilitate the return of postpartum ovarian activity.

The type of birth may also affect the duration of the postpartum anoestrus. Waldron et al. (1999) reported that goat kids had a mean age at first estrus close to 7.5 months, and that in twin-born does this age was four months greater than in single-born does. Joshi et al. (2018) and Zamuner et al. (2020a and 2020b) stated that goats with multiple kids (litter size) showed higher milk production with less fat, increased prolactin and higher mobilization of body reserves resulting in weight and BS loss, associated with plasma elevation of $\beta$-hydroxybutyrate (BHB) and non-esterified fatty acids (NEFA) that act to intensify the NEB, consequently, they may present a more pronounced negative feedback on the hypothalamic-pituitary axis to produce GnRH, FSH and LH and, consequently, a longer period is needed before postpartum ovarian activity reestablishes.

Paez Lama et al. (2016) observed that lengths of suckling period significantly modified resumption of ovarian activity in Creole goat, showing that goats weaned at 30 days postpartum presented an anoestrus period of 102 days compared to 155 days for those weaned at 60 days postpartum.

\section{Nutrition}

According to Van Knegsel et al. (2005), females have high nutritional demands during the last third of gestation due to intense foetal growth. After birth, the demand for energy and protein reaches its highest-level during lactation, causing a negative energy balance (NEB). If these demands are not satisfied, the recovery of ovarian cycles will be delayed both for physiological and nutritional anoestrus (62).

The effects of NEB on fertility are related to metabolic and endocrine changes that affect follicular growth and consequently progesterone production by the corpus luteum (38). According to NRC (2007), postpartum energy intake by goats fluctuates based on the number of kids, milk yield, and body condition at birth. Adequate nutrition is required so that females can deliver their kids with a body condition score between 2.5 and 3.5 (6). 
The effects of nutrition on reproduction are mediated by various hormones. Among them, growth hormone (GH), insulin, and insulin-like growth factor (IGF-I) are important mediators of the effect of the energy balance on follicular growth in bovines (57). Insulin and IGF-I act directly on follicle growth, stimulating folliculogenesis and steroid production by stimulating LH production in the theca cells (31). Oliveira et al. (2013) reported a positive correlation between IGF-I levels and body condition score in cows. Lucy (2008) stated that after parturition, dairy cows are in a catabolic state, with high blood levels of $\mathrm{GH}$, non-esterified fatty acids (NEFA) and $\beta$-hydroxybutyrate (54) and low levels of IGF-I, insulin and GnRH.

Changes may occur in the serum biochemical parameters as aspartate aminotransferase (AST), gamma glutamyl transferase (GGT), triglyceride (TG) whose values can be increased in the postpartum period, signalling the possibility of liver TG infiltration and fatty liver disease (3). He et al. (2015) observed that body reserve mobilization in goats started from the $125^{\text {th }}$ day of pregnancy and caused changes in serum levels with a reduction in glucose levels and increased NEFA and triglycerides; these changes were related to the body condition score. On the other hand, Shi et al. (2015) found no correlation between these parameters and the length of time until the first dominant follicle developed after parturition in JiNing Grey goats.

Wettemann et al. (2014) reported that a lack of glucose reduces the release of hypothalamic GnRH. In contrast, an increase in available glucose causes an increase in insulin levels, stimulating GnRH release. The increase of insulin associated with lower GH levels is important in relation to nutritional impacts on reproduction (32). The functional relation between insulin and GH seems to be anabolic in nature. Growth hormone seems to be associated with the central mediation of metabolic status (34). These authors explain in their review that ovarian follicles do not have receptors for $\mathrm{GH}$, although this hormone operates directly upon luteal cells. GH interacts with insulin to control the hepatic production of IGF-I (42), having opposing actions. When GH is increased the animal is in a catabolic state, and insulin and IGF-I are decreased, because GH promotes the increase of insulin-like growth factor-binding protein (IGFBP), which impairs the synthesis of IGF-I in the liver (31). GH also promotes high levels of NEFA, $\beta$-hydroxybutyrate and adiponectin and low levels of leptin and neuropeptide $Y$, which are signs of lipolysis and, consequently, catabolism $(6,31,54)$. The effects of nutrition on the oestrous cycle are directly mediated by GnRH and gonadotropic hormones, and indirectly through the GH-IGF I-insulin axis (12).

Figure 1 (page 337) shows the possible mechanisms through which nutrition can act upon follicular growth in females with a normal oestrous cycle. The supply of nutrients above maintenance requirements promotes an increase in the plasmatic glucose concentration that in turn has an inhibitory effect on the release of neuropeptide Y. The inhibition of neuropeptide Y promotes the release of GnRH from the hypothalamus, which in turn promotes FSH and LH pulses (9). FSH acts upon ovarian cells, stimulating follicular growth. The increase in LH pulses, together with IGF-I, GH and insulin, stimulates the growth and maturation of follicles. Follicle growth stimulates an increase in metabolism and production of progesterone $\left(\mathrm{P}_{4}\right)$ and estradiol $\left(\mathrm{E}_{2}\right)$. Estradiol acts on the hippocampus, promoting positive feedback, which stimulates the release of GnRH (9). This mechanism is typical in female ruminants with adequate nutrition under favourable environmental conditions.

Small ruminants, in particular goats, which are generally a more prolific species, show some adaptations mainly with regard to follicular dominance e.g. Ginther and Kot (1995) observed that there may be more than one dominant follicle, known as codominance. This phenomenon occurs due to the expression of genes linked to Toll-like receptors, such as WNT4, during follicular selection (14). The codominance is due to the higher FSH pulse which enables the recruitment of a larger number of follicles and growth of more than one follicle, as well as the gene expression action (14); after that the largest LH pulse promotes maturation and ovulation of more than one follicle, these larger pulses of FSH and LH are possible by adequate nutrition under favorable environmental conditions.

Freitas-de-Melo and Ungerfield (2016), in their review, explained that females subjected to unfavourable environmental conditions can present acute or chronic responses that generally occur simultaneously, with the sympathetic response being displayed a few seconds or even minutes after the animal is exposed and the endocrine response takes a little longer to display and it lasts longer (minutes to hours). These responses are physiological and behavioural changes that help the adaptation to the unfavourable environmental conditions, the response intensity may depend on factors of the animal such as previous experience, or adaptations to the adverse environmental conditions from some breeds (20). 
Source: Adapted from Diskin et al. (2003).

Fuente: Adaptado de Diskin et al. (2003).

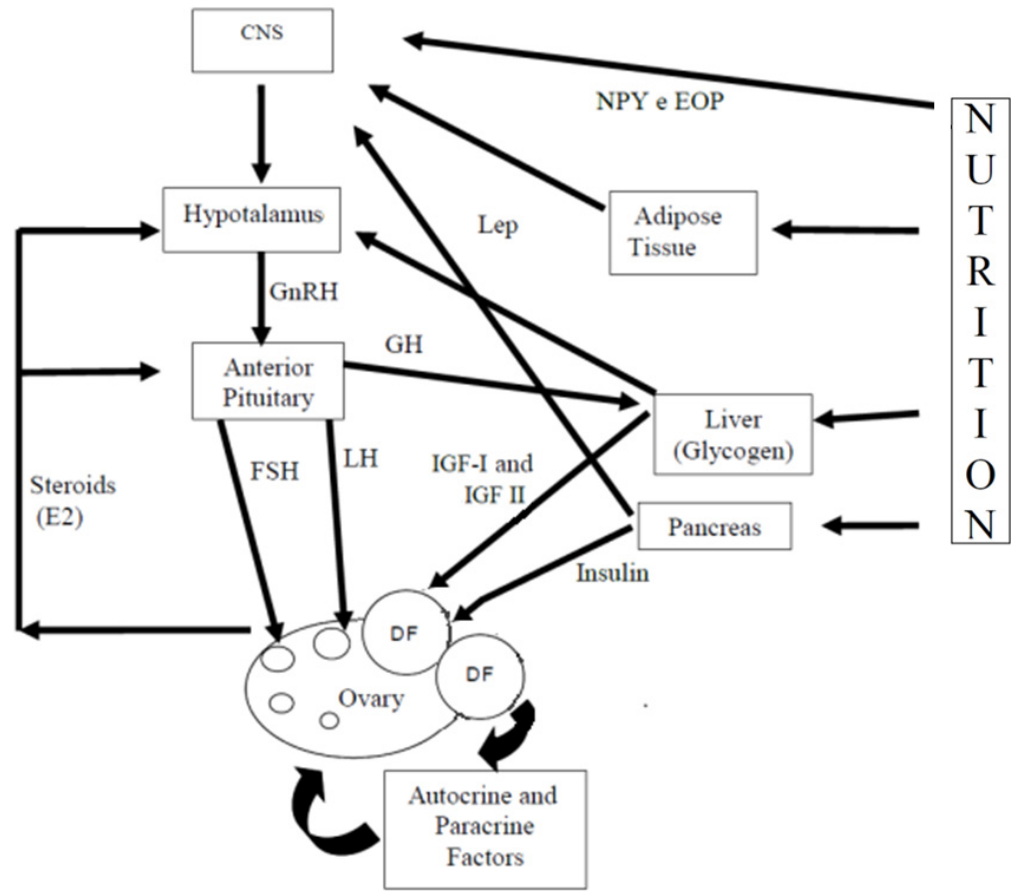

Figure 1. Diagram representing the mechanisms by which nutrition has an impact on ovarian follicular function. CNS: central nervous system, NPY: neuropeptide Y, EOP: endogenous opioid peptide, Lep: leptin; GnRH: gonadotropin releasing hormone; FSH follicle stimulating hormone; LH: luteinizing hormone; DF: dominant follicle; GH: growth hormone;

IGF-I: insulin-like growth factor I; IGF-II: insulin-like growth factor II; E2: oestrogen.

Figura 1. Diagrama que representa los mecanismos por los cuales la nutrición incide sobre la función folicular ovárica. SNC: sistema nervioso central, NPY: neuropéptido Y, EOP: péptido opioide endógeno, Lep: leptina; GnRH: hormona liberadora de gonadotropina; Hormona estimulante del folículo FSH; LH: hormona luteinizante; DF: folículo dominante; GH: hormona del crecimiento; IGF-I: factor de crecimiento similar a la insulina I; IGF-II: factor de crecimiento similar a la insulina II; E2: estrógeno.

The sympathetic response releases the neurotransmitters adrenaline and noradrenaline that increase heart and respiratory rates, temperature and blood glucose concentrations (20). Endocrine response from hypothalamus-pituitary-adrenal axis releases corticotrophin-releasing corticosterone hormone (CRH), adrenocorticotrophic hormone (ACTH) and vasopressin which stimulate the secretion of glucocorticoids, mainly cortisol. This hormone, during long periods of time (from days to weeks), promotes a chronic stress response, generally stimulating high concentrations of glucocorticoids that may negatively affect the immune system and sexual behaviour and appetite (20).

High plasma concentrations of glucose stimulate the pancreas to produce insulin and the liver to produce IGF-I and IGF-II. Glucose is stored as glycogen in the liver and as fat in adipose tissue (9). Energy stored in the adipose tissue increases the metabolism and production of leptin, which also inhibits the release of endogenous opioids and neuropeptide $Y(9)$.

Endogenous opioids and the dopaminergic and serotoninergic systems are associated with nutrition mediate LH pulses (78). Some authors observed that an increase in plasma glucose availability increased GH and insulin secretion, acting directly on the follicular dynamics $(68,75)$. During the initial period of anoestrus, the release of GH and IGF-I is reduced due to low circulating plasma glucose and high levels of NEFA and ketone bodies from lipolysis, especially 3-beta-hydroxybutyrate, which inhibits the pulses of LH $(78,80)$.

Thomas and Williams (1996) confirmed that the ingestion of vegetable oils may increase the bioavailability of cholesterol, a precursor of steroid hormones. Other authors reported that oils are important not only because they are precursors of cholesterol, the 
base molecule for the production of steroid hormones, but also because of their high energy density, which would increase the energy balance and reduce the mobilization of energy reserves (46). Ovarian luteal cells use cholesterol as a precursor for the synthesis of progesterone (75). According to Bao et al. (1995), diets with high concentrations of lipids lead to increased serum concentrations of high-density lipoproteins (HDL). High concentrations of HDL stimulate the production of IGF-I by luteal granulosa cells and may interfere with cyclic ovarian function by modifying the quantity of HDL used for the synthesis of ovarian steroids. Muñoz-Gutiérrez et al. (2002) observed that energy supplements stimulated the recruitment (2-3 $\mathrm{mm}$ and $3-4 \mathrm{~mm}$ ) and selection ( $>6 \mathrm{~mm}$ ) of follicles in ewes. Although these authors did not find any relation between supplements (glucose, glucosamine or lupins) and FSH concentration, they reported that nutritional supplementation might have a direct effect upon follicle production. The addition of fat to the diet stimulates the programmed growth and size of pre-ovulatory follicles and increases the number of follicles (45). Zarazaga et al. (2011) studied the influence of nutrition on LH release and compared two groups of goats with different levels of concentrate in the diet. The high diet group received $700 \mathrm{~g}$ and the low diet group received $350 \mathrm{~g}$ of concentrate, both with $500 \mathrm{~g}$ of barley straw. These diets corresponded to $110 \%$ and $70 \%$ of the daily requirements for maintenance, respectively. They described that goats fed with low diet showed lower LH concentrations, which highlights a positive correlation between diet and LH release.

To reduce the length of postpartum anoestrus in goats, attention should be given to the nutritional requirements during this period, providing supplements with high levels of energy in the first days postpartum, as female goats are unable to ingest a large volume of feed. Supplementary feeding with digestible energy levels above $2.0 \mathrm{Mcal} /$ day/goat weighing $40 \mathrm{~kg}$ is recommended for goats raised in the semiarid region of Brazil (46).

Nogueira et al. (2016) evaluated the reproductive response of goats in seasonal anoestrus that were supplemented with maize (10.6 MJ of Metabolic Energy/day) and/ or hormonally synchronized and observed that maize supplementation for only 9 days increased plasma insulin levels, leptin and IGF-I, and that dietary supplementation associated with oestrus synchronization increased the ovulatory rate of goats by $43 \%$. Nutritionally induced changes in metabolic hormones may have improved the responsiveness of growing follicles to gonadotropins and reduced the rate of atresia, thereby influencing ovulation rate. Supplementation with a relatively small quantity of maize has the potential to increase the ovulation rate in anoestrus when treated with conventional protocol for oestrus synchronization by exogenous hormones, although further investigation with larger groups of animals in seasonally anoestrus goats is needed to verify this conclusion (48).

In a similar study, Nogueira et al. (2017) observed that the ovulatory rate in synchronized goats can be increased when corn supplementation is offered to reach requirements 1.5 times above maintenance (10 MJ of Metabolic Energy/day) when compared to a control diet, without supplementation. Therefore, the addition of $220 \mathrm{~g}$ maize/goat/day for 9 days may promote an increase in ovulatory rate and, consequently, an increase in the number of offspring born. Energy supplementation with maize can provide a readily available source of energy for the microorganisms in the rumen. In summary, Nogueira et al. (2016 and 2017) reported that supplementation with maize (10.6 MJ of Metabolic Energy/day) may improve the responsiveness of growing follicles to gonadotrophins and stimulate ovulation. The positive relationship of corn supplementation on follicle responsiveness as well as on ovulation stimulation may reduce postpartum anoestrus. Nogueira et al. (2017) reported that the nutrition of goats (metabolic status or energetic balance) is the main factor affecting ovulation and corpora lutea and follicular development, by modulating gonadotropin secretion (FSH and LH). These authors demonstrated that undernutrition with a negative energy balance can reduce the follicular recruitment efficiency associated with low ovulation rates in the goat ovary. De Santiago-Miramontes et al. (2008) observed that goats grazing natural vegetation plus supplementation with $1.4 \mathrm{~kg}$ of mixture $69 \%$ of alfalfa hay, $21 \%$ of rolled corn and $10 \%$ of soybean meal) increased the ratio of goats that ovulated (25/25 and 21/25 with and without supplementation, respectively), but not the ratio of females in oestrus (24/25 and 22/25, respectively), which was consistent with Mani et al. (1996). 


\section{Body condition score}

The body condition score (BSC) is a subjective measurement that aims to classify the animals' body energy reserves through their accumulation of fat in some points of the body such as in the chest, ribs, rump and loin, the animals are classified in a fat scale ranging from $1=$ very thin to $5=$ very fat $(10,12)$.

The BSC is the main index representing metabolic status and is important both during gestation and at birth. During the first two thirds of gestation the goat needs to store enough energy for the final third of gestation, during which body reserves are used due to an increase in energy demands from the foetus; during this period, body development is associated to initial milk production (28).

Females must have a good BSC at the end of gestation to enable more rapid postpartum ovarian activity in order to reduce the kidding interval (60). Zarazaga et al. (2005) reported a negative correlation between body condition score or nutritional level, and postpartum anoestrus, such that a low body condition score or low nutritional level extended postpartum anoestrus. The negative effects caused by stress and puerperal NEB can be reduced when the females have a good body condition and those receiving nutritional supplementation (79).

De Santiago-Miramontes et al. (2008) reported that goats with a BSC $<2$ have more abnormal oestrous cycles with a longer time between oestrus and ovulation and fewer oestrous behaviours and ovulations than those with a body condition score $>2.5$, which can be attributed to the reduction in frequency of episodic LH release, which compromises oestrous behaviour, ovarian folliculogenesis and ovulation. These authors explained that the lower body condition score indicates a low energy reserve, and because of this the animals tend to reduce energy expenditure on the maintenance of reproductive activity as an evolutionary characteristic for the survival of the female, a striking characteristic in goats.

He et al. (2015) emphasized that from the $125^{\text {th }}$ day of gestation the mobilization of body reserves is accentuated by the large size of the foetus and the increase in the female's energy demand for both body maintenance and milk production. For these reasons these authors recommended that the body condition score of the female should be monitored and supervised following confirmation of pregnancy to minimize the deleterious effects of the mobilization of energy reserves.

\section{Heat stress}

In the semi-arid region of Brazil a decrease in reproductive activity of small ruminants is commonly associated with the low availability of feeds during the dry season. GarciaIspierto et al. (2006) reported that heat stress can also affect the reproduction of dairy cattle by increasing the secretion of cortisol, which decreases the synthesis of gonadotropic hormones (20). The stress degree can be measured by the level of cortisol $(20,53,69)$. Heat stress produces acute and chronic alterations in the plasmatic concentrations of estradiol and progesterone, causing physiological and behavioural alterations to the oestrous cycle, such as the duration of the oestrous cycle, timing of ovulation and clinical signs of oestrus $(20,44)$.

Several authors have reported longer postpartum anoestrus in goats during the dry season when compared to animals giving birth during the rainy season $(17,37)$. During the dry season, animals grazing on natural pasture can experience a decline in LH secretion due to the severe reduction in feed availability (figure 2, page 340 ).

Several authors have reported that the duration of postpartum anoestrus during the dry or rainy season is associated only with the availability of feed. Torreão et al. (2008) worked with Morada Nova ewes and observed that in rainy season the ratio roughage:concentrated 80:20 (2.2 Mcal ME) compared to 60:40 (2.8 Mcal ME) and 40:60 (3.4 Mcal ME) did not decrease the period of return to cycling activity (ewes fed 2.2 and 3.4 Mcal ME have 34 vs 42 days for ewes fed 2.8 Mcal ME). However in the dry season, these authors observed that animals fed with higher energy levels showed shorter period of return to cycling activity than (58 days in ewes fed 3.4 Mcal ME compared to more than 70 days in ewes fed 2.2 and 2.8 Mcal ME), and showed better reproductive performance suggesting an interaction between seasonal and nutritional factors.

However, researchers in the Brazilian semi-arid region are still searching for further explanations as to how the rainy season has a positive effect on goats' ovarian activity (52). Freitas et al. (2004) associated it with the stress caused by the dry period because of high environmental temperature that promotes heat stress, related with severe reduction in feed availability and quality increasing the secretion of cortisol $(20,41,49,68)$. 
Source: Adapted from Nogueira et al. (2011).

Fuente: Adaptado de Nogueira et al. (2011).

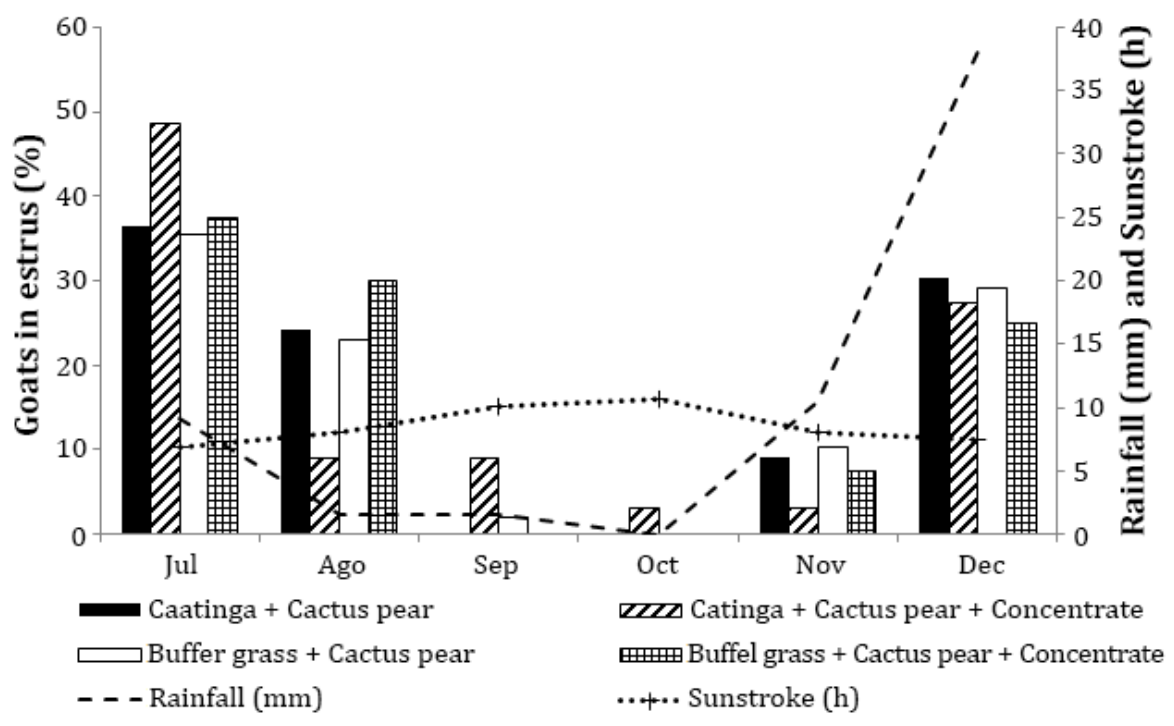

Figure 2. Percentage of goats in oestrus between July and December in 2007 in relation to rainfall, sunstroke and pasture growth.

Figura 2. Porcentaje de cabras en celo entre julio y diciembre de 2007 en relación con las precipitaciones, el fotoperíodo y el crecimiento de las pasturas.

Nogueira et al. (2011) reported a higher concentration of oestrus at the start of the rainy season, probably associated with the cooler temperature, and with the higher quantity and better quality of feed available during this period. According to these authors, the reproductive behaviour of native or crossbred goats of the semiarid region of Brazil was not affected by the different diets offered to the animals. The start of the reproductive activity of goats was more affected by the beginning of the rainy season than the inclusion of concentrated supplement which increased the weight gain of the animals (figure 2). A possible explanation for the rain effect may be related to the reduction in body temperature and thermal sensation of the goats, possibly reducing the effect of thermal stress, therefore decreasing the cortisol levels $(41,49,68)$.

Nogueira et al. (2011) also showed that different diets did not influence oestrus activity during the dry season. This may be associated with the poor quantity and quality of feed offered with the different diets during the study, which may have caused a nutritional deficit during the most critical season of the year. Nascimento et al. (2014a) reported that goats are adapted to heat stress and yet under moderate stress at a wet bulb globe temperature (WBGT) above 85, they can show sexual behaviour when receiving energy supplementation. Carmona et al. (2020) reported that in arid or semi-arid environments the presence of agroecological productive systems can collaborate to minimize the heat stress in the herds.

Despite differences in authors' studies regarding the importance of nutrition on postpartum anoestrus, there is sufficient evidence that it is possible to shorten the anoestrus period through strategic supplementation. Nascimento et al. (2014b) reported that postpartum anoestrus in goats during the dry season can be reduced by the addition of concentrate with high levels of energy. These authors observed a negative linear effect: the higher the level of energy in the diet, the shorter time for uterine involution and postpartum anoestrus. Further evidence is referenced in different sections of this review to support the relationship between postpartum anoestrus and nutrition.

\section{Social interactions}

Paez Lama et al. (2016) agreed that the nutritional and endocrinological factors discussed in this review are important but attributed the length of postpartum anoestrus to the doekid relation in the suckling period. They found that the suckling period promoted a statistically significant change in the anoestrus period independent of the energy supplementation and pointed out that the weaning time determined the duration of the anoestrus period. 
The use of the male effect to reduce the anoestrus period in small ruminants is mainly reported in places with latitudes above $25^{\circ}$. The "male effect" is a cheap and common technique used to stimulate female's sexual activity and, according to the literature, exposure of females to sexually active bucks can induce the secretion of LH and thereby promote ovulation; in seasonal anovulatory goats just 15 minutes of female-male contact was enough to reactivate GnRH-LH secretion and consequently promote oestrous behaviour and ovulation (58). The use of the male effect is a resource widely used in the different species of domestic ruminants in sheep $(2,5,8,18)$, cattle $(43,66)$, goats $(8,71)$.

Cattle showed an interaction between the BSC and the male effect, females of high BSC (fat) tend to be less responsive to the male effect than cows with moderate BSC (66). Monje et al. (1992) observed that cows feeding diets with nutritional intake above requirements were more responsive to the male effect, but when they receive a diet with nutritional intake below requirements, the presence of bulls showed no influence on the length of postpartum anoestrus.

Delgadillo et al. (2009) pointed out that social interactions are complex, and possible, there is an effect of the combination of social interactions, i.e. ram effect combined with temporary weaning, corroborating data from other authors (18).

\section{RECOMMENDATIONS}

To minimize the negative effects of postpartum anoestrus, we recommend that the mating season and the kidding period should be planned according to the wet season, and that body condition during pregnancy should be monitored in order to implement a nutritional supplementation with levels of energy above the requirements for maintenance so that females present an acceptable body condition at parturition.

\section{Conclusion}

The duration of postpartum anoestrus in goats directly conditions the productivity of the herd and is influenced by different factors, mainly nutrition, lactation period and, in the north-eastern region of Brazil, by heat stress.

\section{REFERENCES}

1. Ababneh, M. M.; Degefa, T, 2005. Ultrasonic assessment of puerperal uterine involution in Balady goats In Journal of Veterinary Medicine and Animal Physiology Pathology and Clinical Medical. 52(5): 244-248.

2. Abecia, J. A.; Chemineau, P.; Gómez, A.; Palacios, C.; Keller, M.; Delgadillo, J. A. 2017. Exposure to photoperiod-melatonin-induced, sexually activated rams after weaning advances the resumption of sexual activity in post-partum Mediterranean ewes lambing in January. In Veterinary Sciences. 4(1): 4.

3. Akkaya, F.; Senturk, S.; Mecitoğlu, Z.; Kasap, S.; Ertunc, S.; Kandemir, C. 2020. Evaluation of metabolic profiles of Saanen goats in the transition period. In Journal of the Hellenic Veterinary Medical Society, 71(2), 2127-2134.

4. Angrimani, D. de S.R.; Rui, B. R.; Cruz, L. V. da; Romano, R. M.; Lopes, H. C. 2011. Retenção de placenta em vacas e éguas: revisão de literatura. In Revista cientifica eletrônica de medicina veterinária, 16.

5. Ascari, I. J.; Alves, N. G.; Alves, A. C.; Garcia, I. F. F.; Junqueira, F. B. 2016. Resumption of cyclic ovarian activity in postpartum ewes: a review. In Semina: Ciências Agrárias. 37(2): 1101-1115.

6. Bao, B.; Thomas, M. G.; Griffith, M. K.; Burghardt, R. C.; Williams, G. L. 1995. Steroidogenic activity, insulin-like-growth factor I production, and proliferation of granulosa and theca cells obtained from dominant pre-ovulatory and non-ovulatory follicles during the bovine estrous cycle: effects of low-density and high-density lipoproteins. In Biology Reproduction, 53: 1271-1279.

7. Carmona Crocco, J.; Greco, S.; Tapia, R.; Martinelli, M. 2020. Use of indicators as a tool to measure sustainability in agroecosystems of arid land, San Juan, Argentina. Revista de la Facultad de Ciencias Agrarias.Universidad Nacional de Cuyo. Mendoza. Argentina. 52(1): 190-209. 
8. Cezar, M. F.; Sousa, W. H. 2010. Proposal for the evaluation and classification of carcasses of sheep and goats. Tecnologia e Ciência Agropecuária. 4: 41-51.

9. Degefa, T.; Ababneh, M. M.; Moustafa, M. F. 2006 Uterine involution in the post-partum Balady goat In Veterinarski Arhiv. 76(2):119-133.

10. Delgadillo, J. A.; Gelez, H.; Ungerfeld, R.; Hawken, P. A.; Martin, G. B. 2009. The male effect' in sheep and goats-revisiting the dogmas. In Behavioural Brain Research. 200(2): 304-314.

11. De Santiago-Miramontes, M. A.; Rivas-Muñoz, R.; Muñoz-Gutiérrez, M.; Malpaux, B.; Scaramuzzi, R. J.; Delgadillo, J. Á. 2008. The ovulation rate in anoestrous female goats managed under grazing conditions and exposed to the male effect is increased by nutritional supplementation. In Animal Reproduction Science. 105(3-4): 409-416.

12. De Santiago-Miramontes, M. A.; Malpaux, B.; Delgadillo, J. A. 2009. Body condition is associated with a shorter breeding season and reduced ovulation rate in subtropical goats. In Animal Reproduction Science, 114: 175-182.

13. Diskin, M. G.; Mackey, D. R.; Roche, J. F.; Screenan, J. M. 2003. Effects of nutrition and metabolic status on circulating hormones and ovarian follicle development in cattle. In Animal Reproduction Science. 78: 345-370.

14. Dobek, E.; Gorski, K.; Romanowicz, K.; Misztal, T. 2013 Different types of opioid receptors involved in the suppression of LH secretion in lactating sheep. In Animal Reproduction Science. (141): 62-67.

15. Eloy, A. M. X.; Andriolli, A.; Simplicio, A. A. 2003. Atividade ovariana no pós-parto de cabras SRDs (sem raça definida) no Nordeste do Brasil. In Ars Veterinaria, 19(2): 166-171.

16. Falcão, D. P.; Santos, M. H. B.; Freitas Neto, L. M.; Neves, J. P. N.; Lima, P. F.; Oliveira, M. A. L. 2008. Uso da PGF2 $\alpha$ no puerpério para reduzir o anestro pós-parto de cabras em aleitamento contínuo e controlado. In Ciencia Animal Brasileira. 9(2): 512-518.

17. Faraz, A.; Waheed, A.; Nazir, M. M.; Hameed, A.; Tauqir, N. A.; Mirza, R. H.; Ishaq, H. M.; Bilal, R. M. 2020. Impact of oxytocin administration on milk quality, Reproductive performance and residual effects in dairy animals-A Review. In Punjab University Journal of Zoology, 35(1):61-67.

18. Fatet, A.; Pellicer-Rubio, M. T.; Leboeuf, B. 2011. Reproductive cycle of goats. In Animal Reproduction Science. 124: 211-219.

19. Ferreira-Silva, J. C.; Tenório Filho, F.; Moura, M. T.; Nascimento, P. S.; Oliveira, L. R. S.; Bartolomeu, C. C.; Oliveira, M. A. L. 2018. Follicular size, luteinizing hormone (LH), and progesterone (P4) levels in postpartum Santa Inês ewes subjected to ram effect combined with suckling interruption. In Livestock Science. 214: 88-92.

20. Freitas, V. J. F.; Rondina, D.; Nogueira, D. M.; Simplício, A. A. 2004. Post-partum anoestrus in Anglonubian and Saanen goats raised in the semi-arid region of Northeast of Brazil. In Livestock Production, 90(2-3): 219-226.

21. Freitas-de-Melo, A.; Ungerfeld, R. 2016. Progesterone and stress response: mechanisms of action and its impact in domestic ruminants. Review. In Revista Mexicana de Ciencias Pecuarias. $7(2):$ 185-199.

22. Gaafar, K. M.; Gabr, M. K.; Teleb, D. F. 2005. The hormonal profile during the estrous cycle and gestation in Damascus goats (Technical note). In Small Ruminant Research. 57: 85-93.

23. Garcia-Ispierto, I.; López-Gatius, F.; Santolaria, P. 2006. Relationship between heat stress Durant the peri-implantation period and early fetal loss in dairy cattle. In Theriogenology. 65: 799-807.

24. Ginther, O. J.; Kot, K. 1994. Follicular dynamics during the ovulatory season in goats. In Theriogenology. 42(6): 987-1001.

25. González-Stagnaro, C. 1993. Comportamiento reproductivo de ovejas y cabras tropicales In Revista Cientifica- FCV-LUZ. 3(3): 173-195.

26. Gordon, K.; Renfree, M. B.; Short, R. V.; Clarke, I. J. 1987 Hypothalamo-pituitary portal blood concentrations of $ß$-endorphin during suckling in the ewe. In Journal Reproduction and Fertility. 70: 397-408.

27. Greyling, J. P. C.; Van Niekerk, 1991. C. H. Macroscopic uterine involution in the postpartum Boer goat. In Small Ruminant Research. 4(3): 277-283.

28.HeZXSun,Z.H.; Beauchemin,K.A.;Yang,W.Z.;Tang,S.X.;Zhou,C.S.;Han,X.F.;Wang,M.;Kang,J.H.;Tan,Z.L. 2015. Effect of protein or energy restriction during late gestation on hormonal and metabolic status in pregnant goats and postnatal male offspring. In Animal. 9(11): 1843-1851.

29. Joshi, A.; Kalauni, D.; Bhattarai, N. 2018. Factors affecting productive and reproductive traits of indigenous goats in Nepal. In Archives of Veterinary Science and Medicine. 1(1):19-27.

30. Kandiel, M. M. M.; Watanabé, G.; Abou-El-Roos, M. E. A.; Abdel-Ghaffar, A. E.; Sosa, G. A.; El-Azab, A. M.; El-S, I.; Nagaoka, K.; Li, J. Y.; Manabé, N.; Kazuyoshi, T. 2012. Follicular turnover and hormonal association in postpartum goats during early and late lactation. In Journal of Reproduction Development. 58(1): 61- 68.

31. Krajničáková, M.; Bekeová, E.; Lenhardt, L.; Cigánková, V.; Valocky, I.; Maraček, I. 1999. Microscopic analysis of the uterine endometrium in postparturient ewes. In Acta Veterinary Brno. 68: 9-12.

32. Lucy, M. C. 2008. Functional differences in the growth hormone and insulin-like growth factor axis in cattle and pigs: implications for post-partum nutrition and reproduction. In Reproduction Domestic Animal. 43: 31-39. 
33. Madureira, E. H.; Fernandes, R. H. R.; Rossa, L. A. F.; Pimentel, J. R. V.; Braga, F. A.; Pardo, F. J. 2006. Anestro pós-parto em bovinos: a suplementação com óleos vegetais pode ser útil para encurtá-lo? In: Simpósio Internacional de reprodução animal aplicada. Londrina. p. 63-70.

34. Mahdi, D.; Khallili, 2008. K. Relationship between follicle growth and circulating gonadotrophin levels during postnatal development of sheep. In Animal Reproduction Science, 106:100-112.

35. Maia, M. da S.; Costa, N. A. 1998. Estro e atividade ovariana pós-parto em cabras Canindé, associadas ao manejo da amamentação. In Revista Brasileira de Reprodução Animal. 22: 55-43.

36. Mani, A. U.; McKelvey, W. A. C.; Watson, E. D. 1996. Effect of undernutrition on gonadotrophin profiles in non-pregnant, cycling goats. In Animal Reproduction Science. 43(1): 25-33.

37. Mazerbourg, S.; Bondy, C. A.; Zhou, J.; Monget, P. 2003. The insulin-like growth factor system: A key determinant role in the growth and selection of ovarian follicles? A comparative species study. In Reproduction in Domestic Animal. 38: 247-258.

38. Mbayahaga, J.; Mandiki, S. N. M.; Bister, J. L.; Paquay, R. 1998. Body weight, oestrous and ovarian activity in local Burundian ewes and goats after parturition in the dry season. In Animal Reproduction Science. 51: 289-300.

39. McGregor, B. A. 2005. Nutrition and management of goats in drought. In Rural Industry Research and Development Corporation. 1: 1-90.

40. Mendoza, G. D.; Oviedo, M. F.; Pinos, J. M.; Lee-Rangel, H. A.; Vázquez, A.; Flores, R.; Pérez, F.; Roque, A.; Cifuentes, 0. 2020. Milk production in dairy cows supplemented with herbal choline and methionine. Revista de la Facultad de Ciencias Agrarias. Universidad Nacional de Cuyo. Mendoza. Argentina. 52(1): 332-343.

41. Meza-Herrera, C. A.; Hallford, D. M.; Ortiz, J. A.; Cuevas, R. A.; Sanchez, J. M.; Salinas, H.; Mellado, M.; Gonzalez-Bulnes, A. 2008. Body condition and protein supplementation positively affect periovulatory ovarian activity by non LH-mediated pathways in goats. In Animal Reproduction Science. 106: 412-420.

42. Mirzaei, F.; Prasad, S.; Preston, T. R. 2011. Influence of a dietary phytoadditive on the performance of does and respective litters in cross bred dairy goats. In Journal of Animal and Plant Science. 10(1):1259- 1267.

43. Molento, C. F. M.; Block, E.; Cue, R. I.; Peticlerc, D. 2002. Effects of insulin, recombinant bovine somatotropin, and their interaction on insulin-like growth factor I secretion on milk production in dairy cows. In Journal of Dairy Science. 85: 738-747.

44. Monje, A. R.; Alberio, R.; Schiersmann, G.; Chedrese, J.; Carou, N.; Callejas, S. S. 1992. Male effect on the post-partum sexual activity of cows maintained on two nutritional levels. In Animal Reproduction Science. 29(1-2): 145-156.

45. Morais, D. A. E. F.; Lima, F. R. G.; Vasconcelos, A. M. de; Lima, P. O.; Morais, J. H. G. 2008. Manifestação de estro, fertilidade e desempenho reprodutivo de cabras leiteiras de diferentes raças em ambiente quente. In Revista Caatinga. 21(2): 62-67.

46. Muñoz-Gutiérrez, M.; Blanche, D.; Martin, G. B.; Scaramuzzi, R. J. 2002. Folliculogenesis and ovarian expresión of RNA encoding aromatase in anoestrous sheep after 5 days of glucose or glucosamine infusion or supplementary lupin feeding. In Reproduction. 124: 721-731.

47. Nascimento, T. V. C.; Miranda, M. de S.; Barros, C. H. S. C.; Souza, T. T. dos S.; Lopes Júnior, E. S.; Voltolini, T. V.; Moraes, S. A. de; Nogueira, D. M.; Cordeiro, M. F. 2014a. Return of postpartum ovarian activity in dairy goats supplemented with different levels of energy. In Revista Brasileira de Saúde e Produção Animal. 15: 1061-1071.

48. Nascimento, T. V. C.; Oliveira, F. A. de; Turco, S. H. N.; Cordeiro, M. F.; Lopes Júnior, E. S. 2014b. Fatores meteorológicos sobre a atividade reprodutiva de cabras leiteiras na época seca do semiárido pernambucano. In Revista Brasileira de Engenharia Agrícola. 18(5): 539-544.

49. Nogueira, D. M.; Freitas, V. J. F. 2000. Anestro pós-parto em caprinos: uma revisão. In Ciência Agrotecnica. 2(2): 33-40.

50. Nogueira, D. M.; Voltolini, T. V.; Moreira, J. N.; Lopes Júnior, E. S.; Oliveira, V. G. de A. 2011. Effect of alimentary regimes on body weight and reproductive parameters of native goats. In Archives of Zootecnia. 60: 1339-1342.

51. Nogueira, D. M.; Cavalieri, J.; Fitzpatrick, L. A.; Gummow, B.; Blache, D.; Parker, A. J. 2016. Effect of hormonal synchronisation and/or short-term supplementation with maize on follicular dynamics and hormone profiles in goats during the non-breeding season. In Animal Reproduction Science. 171: 87-97.

52. Nogueira, D. M.; Eshtaeba, A.; Cavalieri, J.; Fitzpatrick, L. A.; Gummow, B.; Blache, D.; Parker, A. J. 2017. Short-term supplementation with maize increases ovulation rate in goats when dietary metabolizable energy provides requirements for both maintenance and 1.5 times maintenance. In Theriogenology. 89: 97-105.

53. NRC. 2007. Nutrient requirements of small ruminants: Sheep, goats, cervids, and new world camelids. Washington. DC.

54. Oba, E.; Souza, M. I. L.; Uribe-Velasquez, L. F. V.; Ramos, A. A. 2001. Concentrações plasmáticas e ritmo circadiano de cortisol e prolactina (PRL) em ovelhas, durante a anestro estacional. In Arquivos de Ciências Veterinárias e Zoologia. 4(2): 169-174. 
55. Obese, F. Y.; MacCarthy, C.; Osei-Amponsah, R.; Ayizanga, R. A.; Damptey, J. K. 2015. Blood metabolite profiles in cycling and non-cycling Friesian-Sanga cross-bred cows grazing natural pasture during the post-partum period. In Reproduction in Domestic Animal. 50: 304-311.

56. Oliveira, T. S. de; Rodrigues, M. T.; Lima, M. C.; Vieira, R. A. M.; Oliveira, V. S. de; Alves, T. M. O. 2013. Variação das massas de gordura e proteína corporal e dos órgãos viscerais de cabras Alpinas nos 60 dias de lactação. In Revista Brasileira de Saúde e Produção Animal. 14(4): 672-683.

57. Paez Lama, S. A.; Grilli, D.; Egea, V.; Fucili, M.; Allegretti, L.; Guevara, J. C.; Jahn, G. A. 2016. Effect of the length of the suckling period and dietary energy intake in lactation on the duration of postpartum anestrus in Creole goats. In Small Ruminant Research, 139: 1-6.

58. Rabassa, V. R.; Pfeifer, L. F. M.; Schneider, A.; Luz, E. M. da; Costa, E. R. M.; Corrêa, M. N. 2007. Anestro pós-parto em bovinos: mecanismos fisiológicos e alternativas hormonais visando reducir este período-uma revisão. In Revista FZVA. 14(1): 139-161.

59. Ramírez, S.; Bedos, M.; Chasles, M.; Hernández, H.; Flores, J. A.; Vielma, J.; Duarte, G.; Retana Márquez, M. S.; Keller, M.; Chemineau, P.; Delgadillo, J. A. 2017. Fifteen minutes of daily contact with sexually active male induces ovulation but delays its timing in seasonally anestrous goats. In Theriogenology. 87: 148-153.

60. Rivas-Muñoz, R.; Carrillo, E.; Rodriguez-Martinez, R.; Leyva, C.; Mellado, M. F.; Véliz, G. 2010. Effect of body condition score of does and use of bucks subjected to added artificial light on estrus response of Alpine goats. In Tropical Animal Health and Production. 42: 1285-1289.

61. Salmazo, R.; Mizubuti, I. Y.; Moreira, F. B.; Rocha, M. A. da; Ribeiro, E. L. A.; Seneda, M. M.; Hiroki, P.T.; Krawulski, C. C.; Rigo, A. G.; Schroeder, R. V. 2008. Efeito de diferentes níveis de suplementação concentrada sobre o desempenho reprodutivo de vacas leiteiras mantidas a pasto. In Ciência Agrária. 29(3): 731-740.

62. Salmito-Vanderley, C. S. B.; Marques Júnior, A. P. 2004. Involução uterina em cabras sem raça definida. In Revista Brasileira de Reprodução Animal. 28(3): 278-281.

63. Schirar, A.; Cognie, Y.; Louault, F.; Poulin, N.; Levasseur, M. C.; Martinet, J. 1989a. Resumption of oestrous behaviour and cyclic ovarian activity in suckling and non-suckling ewes. In Journal of Reproducion and Fertility. 87(2): 789-794.

64. Schirar, A.; Meusnier, C.; Paly, J.; Levasseur, M. C.; Martinet, J. 1989b. Resumption of ovarian activity in post-partum ewes: role of the uterus. In Animal Reproduction Science. 19(1-2): 79-89.

65. Shi, Y.; Wang, S.; Bai, S.; Huang, L.; Hou, Y. 2015. Postnatal ovarian development and its relationship with steroid hormone receptors in JiNing Grey goats. In Animal Reproduction Science. 154: 39-47.

66. Spicer, L. J.; Chase Junior, C. C.; Rutter, L. M. 2002. Relationship between serum insulin-like growth factor-I and genotype during the postpartum interval in beef cows. In Journal Animal Science. 80: 716-722.

67. Stumpf, T. T.; Wolfe, M. W.; Wolfe, P. L.; Day, M. L.; Kittok, R. J.; Kinder, J. E. 1992. Weight changes prepartum and presence of bulls postpartum interact to affect duration of postpartum anestrus in cows. In Journal of Animal Science. 70(10): 3133-3137.

68. Takayama, H.; Tanaka, T.; Kamomae, H. 2010. Postpartum ovarian activity and uterine involution in non-seasonal Shiba goats, with or without nursing. In Small Ruminant Research. 88(1): 62-66.

69. Thomas, M. G.; Williams, G. L. 1996. Metabolic hormone secretion and FSH-induced superovulatory responses of beef heifers fed dietary fat supplements containing predominantly saturated or polyunsaturated fatty acids. In Theriogenology. 45: 451-458.

70. Torreão, J. N. C.; Pimenta Filho, E. C.; Medeiros, N. A.; Gonzaga Neto, S.; Catanho, M. T. J. A.; Barreto, L. M. G.; Silva, J. 0. 2008. Retorno da atividade cíclica reprodutiva em ovelhas da raça Morada Nova, submetidas a diferentes níveis de energia metabolizável. In Revista Brasileira de Saúde e Produção Animal. 9(3):621-630.

71. Van Knegsel, A. T. M.; Van den Branda, H.; Dijkstra, J.; Tamminga, S.; Kemp, B. 2005. Effect of dietary energy source on energy balance, production, metabolic disorders and reproduction in lactating dairy cattle. In Reproduction of Nutrition and Development. 45: 665-688.

72. Véliz, F. G.; Moreno, S.; Duarte, G.; Vielma, J.; Chemineau, P.; Poindron, P.; Malpaux, B.; Delgadillo, J. A. 2002. Male effect in seasonally anovulatory lactating goats depends on the presence of sexually active bucks, but not estrous females. In Animal Reproduction Science. 72(3-4): 197-207.

73. Waldron, D. F.; Willigham, T. D.; Thompson, P. V.; Eckhoff, R. G.; May, B. J. 1999. Age at first estrus, ovulation rate, and age at anestrus in puberal Boer Spanish and Spanish does. In Small Ruminant Research. 31: 173-176.

74. Webb, R.; Garnsworthy, P. C.; Campbell, B. K.; Hunter, M. G. 2007. Intra-ovarian regulation of follicular development and oocyte competence in farm animals. In Theriogenology. 68S: S22-S29.

75. Wettemann, R. P.; Lents, C. A.; Ciccioli, N. H.; White, F. J.; Rubio, I. 2003. Nutritional and suckling mediated anovulation in beef cows. In Journal of Animal Science. 81: 48-59.

76. Williams, G. L.; Stanko, R. L. 1999. Dietary fats as reproductive nutraceuticals in beef cattle. In Proceedings of the American Society of Animal Science.

77. Zamuner, F.; DiGiacomo, K.; Cameron, A. W. N.; Leury, B. J. 2020a. Effects of month of kidding, parity number, and litter size on milk yield of commercial dairy goats in Australia. In Journal of Dairy Science. 103(1): 954-964. 
78. Zamuner, F.; DiGiacomo, K.; Cameron, A. W. N.; Leury, B. J. 2020b. Endocrine and metabolic status of commercial dairy goats during the transition period. In Journal of Dairy Science. 103(6): 5616-5628.

79. Zarazaga, L. A.; Guzmán, J. L.; Domínguez, C.; Pérez, M. C.; Prieto, R. 2005. Effect of plane of nutrition on seasonality of reproduction in Spanish Payoya goats. In Animal Reproduction Science. 87: 253-267.

80. Zarazaga, L. A.; Celi, I.; Guzmán, J. L.; Malpaux, B. 2011. The role of nutrition in the regulation of Luteinizing hormone secretion by the Opioidergic, Dopaminergic, and Serotonergic systems in female Mediterranean goats. In Biology of Reproduction. 84: 447-454.

\section{ACKNOWLEDGEMENTS AND CONFLICT OF INTEREST}

This study are from the master's thesis of the first author in Posgraduates program Animal Sciences of Universidade Federal do Vale do São Francisco (UNIVASF).

This study was made possible by a grant from the Foundation for Research Support of the Pernambuco State (FACEPE) and Coordination for the Improvement of Higher Education Personnel (CAPES) for the scholarships.

There are no conflicts of interest issues concerning this submission. 